\title{
The changing landscape of military medical malpractice: from the Feres Doctrine to present
}

\author{
Callum D. Dewar, MD, ${ }^{1}$ Jason H. Boulter, MD,,2 Brian P. Curry, MD, ${ }^{1,2}$ Dana M. Bowers, JD, ${ }^{3}$ and \\ Randy S. Bell, MD',2
}

\begin{abstract}
'Division of Neurosurgery, Walter Reed National Military Medical Center, Bethesda; 'Department of Surgery, Uniformed Services University of the Health Sciences, Bethesda; and ${ }^{3}$ Office of General Counsel, Walter Reed National Military Medical Center, Bethesda, Maryland

Medical malpractice suits within the military have historically been limited by the Feres Doctrine, a legal precedent arising from a Supreme Court decision in 1950, which stated that active-duty personnel cannot bring suit for malpractice against either the United States government or military healthcare providers. This precedent has increasingly become a focus of discussion and reform as multiple cases claiming malpractice have been dismissed. Recently, however, the National Defense Authorization Act of 2020 initiated the first change to this precedent by creating an administrative body with the sole purpose of evaluating and settling claims of medical malpractice within the military's $\$ 50$ billion healthcare system. This article seeks to present the legal history related to military malpractice and the Feres Doctrine as well as discuss the potential future implications that may arise as the Feres Doctrine is modified for the first time in 70 years. https://thejns.org/doi/abs/10.3171/2020.8.FOCUS20594
\end{abstract}

KEYWORDS Feres Doctrine; military medicine; military malpractice; 2020 National Defense Authorization Act

$\mathrm{O}$ N July 3, 1945, an aviation mechanic in the United States Army underwent a cholecystectomy at Fort Belvoir Community Hospital, a military treatment facility (MTF) in Virginia. Following his honorable discharge from the military in 1946, he sought treatment at Johns Hopkins University Hospital in Baltimore, Maryland, for progressive nausea and emesis. During surgery at Johns Hopkins, a 30-inch by 18-inch surgical towel bearing the legend "Medical Department U.S. Army" was discovered in his abdomen and removed. The civil suit that ensued alleged that the towel was left in his abdomen as a result of negligence during his surgery at Fort Belvoir, and while it was determined as a matter of fact that negligence had occurred, the court held that as a matter of law, the United States government could not be held liable.

This case, Jefferson $v$ United States, was one of the original tests of the ability of servicemembers or their families to seek recompense from the United States government for injuries occurring as a result of negligent medical care, and has formed the basis for subsequent interpretations of federal liability for medical malpractice. Courts have almost uniformly held that members of the armed forces cannot sue the government in such circumstances. ${ }^{1,2}$ Recent legislation, however, has provided servicemembers and their families with an avenue to obtain some degree of compensation. In the following article, we present the historical barriers to litigation for military medical malpractice, and consider this new legislation and its implications for the future of military medicine.

\section{The History of Military Medical Malpractice}

Civil litigation against the United States government is permitted under the Federal Tort Claims Act (FTCA 1946), which waives sovereign immunity and allows individuals to bring a claim against the government. ${ }^{2,3}$ An important exception to the legal remedies provided by the FTCA, however, is in the special case of injuries related to active-duty service in the military, even when those injuries are caused by negligence on the part of the federal government or its representatives. This interpretation of the FTCA forms the basis of the Feres Doctrine.

In 1950, three civil suits were brought against the United States under the FTCA, two of which involved allegations of medical malpractice. ${ }^{3}$ These cases were subsequently combined into one unanimous United States Supreme Court opinion (Feres $v$ United States, 340 US 135 [1950]). Based on three lines of reasoning, the court held that the government is not liable for the injuries suffered by servicemembers when those injuries are incident to their mil- 


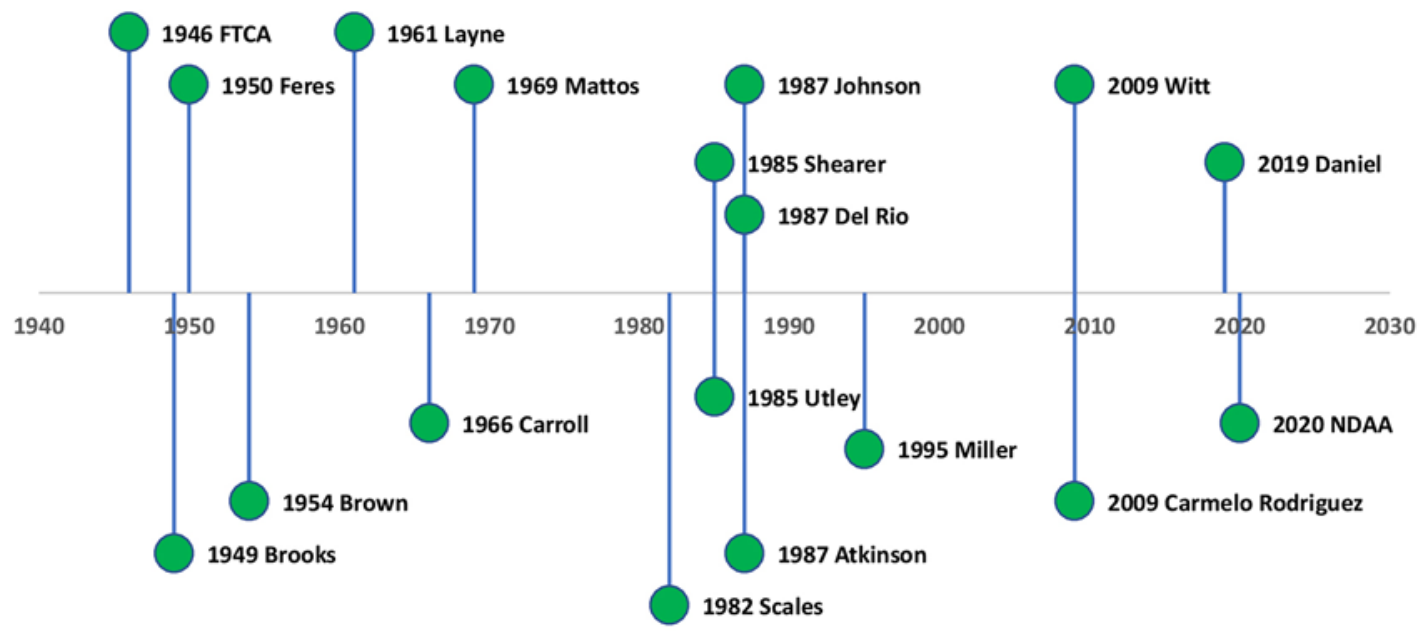

FIG. 1. Timeline of military medical malpractice claims. This figure displays some of the pertinent attempted tort claims discussed against the United States government in chronological order. ${ }^{1,3-18,23,32}$

itary service. First, although the FTCA assigns to the government tort liability similar to a private individual under "like circumstances," there are clear differences between the United States military and private individuals (e.g., individuals are not legally entitled to conscript and mobilize private military forces). Allowing servicemembers to pursue damages for injuries incident to military service would therefore expose the government to "novel and unprecedented liabilities." Second, although the FTCA defers to the laws of the state in which negligence is alleged to have occurred, the relationship between servicemembers and the military is federal in nature, and personnel are relocated at the discretion of the federal government. Thus, the court argued that it would be inappropriate for military compensation to be based on location. Finally, the court argued that if the FTCA had intended to allow for compensation for military malpractice suits, the legislators would have provided a method for adjusting Veterans Administration disability benefits based on the compensation provided. ${ }^{1,2}$

Despite frequent would-be tort claims from injured soldiers and dependents, the precedent has been consistently upheld over the past 70 years, even while many decisions have been critical of its principles. ${ }^{4-15}$ Even in decisions that have openly criticized the Feres Doctrine, case after case has upheld its principles. ${ }^{15,16}$ Unable to reverse decades of precedent, several courts have more strictly defined who is and is not subject to the Feres Doctrine. For example, some have excluded discharged veterans injured at Veterans Administration hospitals, whereas others decidedly include military reservists injured or killed in training exercises ${ }^{4,6,7}$ (Fig. 1, Table 1).

In the mid-2000s, as the United States found itself embroiled in Operation Enduring Freedom and Operation Iraqi Freedom, an attempt at reform through legislation was proposed. The Carmelo Rodriguez Military Medical Accountability Act of 2009 sought to allow for claims for personal injury or death of servicemembers from medical negligence in a military setting. ${ }^{17}$ Under heavy criticism of its estimated $\$ 2.7$ billion price tag, though, it ultimately failed to pass. ${ }^{17-19}$

\section{The Ethics of the Feres Doctrine}

Critics of the Feres Doctrine have generally focused on three main points. First and most obviously, the inability of servicemembers to seek compensation from the government for medical malpractice results in a loss of autonomy and rights. This is compounded by the fact that whether and how much compensation is provided to patients or their dependents is determined by the very same entity alleged to have committed the negligent act.

Second, whereas medical care delivered in the forwarddeployed setting is explicitly not subject to the FTCA, the majority of medical care provided to servicemembers is conducted outside of combat zones in modern medical centers. ${ }^{17}$ Therefore, there should be no military-related reason why such patients should not expect and receive the same care that they would in a civilian hospital, and thus there should be no reason why they would not be able to sue should their care deviate from the standard of care. ${ }^{20}$

Finally, critics of the Feres Doctrine note that the stated rationale for upholding the precedent has changed drastically over the years, evolving from the argument advanced in the original decision in 1946 to include protecting military unity, preventing second-guessing of orders, and preventing minimization of wartime injuries by rewarding malpractice injuries at a higher monetary value. The everchanging explanations for upholding the Feres Doctrine, they argue, suggest a weak legal foundation, and are instead used by the judiciary to avoid actually analyzing the merits of individual cases. ${ }^{2,21}$

In response, proponents of the Feres Doctrine maintain that increased litigation does not solve the issues at hand. Rather than leaving compensation subject to the court, they hold it would be more just for Congress to create a system or provision for restitution for servicemembers injured by negligent care. Also, they note that because the FTCA permits action against the United States government and not the allegedly negligent individual, litigation in these cases would have minimal impact on changing the behavior of military healthcare providers. In any event, there is already a mechanism for reporting negligent military 
TABLE 1. Details on legislation and court decisions regarding military malpractice (1946-2020)

\begin{tabular}{|c|c|c|}
\hline Event & Details/Allegations & Court Decision \& Implication \\
\hline Feres v United States, $1950^{1}$ & $\begin{array}{l}\text { 1. Feres-active-duty servicemembers perished by fire in the } \\
\text { barracks. } \\
\text { 2. Jefferson-towel left in abdominal cavity postsurgery. } \\
\text { 3. Griggs-alleged negligence and unskillful medical treatment by } \\
\text { army surgeon. }\end{array}$ & $\begin{array}{l}\text { Government is not liable under the FTCA for injuries } \\
\text { to servicemembers when the injuries arise out of } \\
\text { or are in the course of activity incident to service. }\end{array}$ \\
\hline $\begin{array}{l}\text { United States v Brown, } \\
1954^{4}\end{array}$ & Nerve damage, defective tourniquet postsurgery. & $\begin{array}{l}\text { A discharged veteran can file tort claims for injury } \\
\text { suffered after discharge. }\end{array}$ \\
\hline Layne v United States, $1961^{5}$ & Fatal crash during training mission. & Officer's widow could not sue the US for negligence. \\
\hline $\begin{array}{l}\text { United States v Carroll, } \\
1966^{6}\end{array}$ & $\begin{array}{l}\text { Reservist suffered injuries sustained as a passenger in a military } \\
\text { aircraft. }\end{array}$ & Feres Doctrine applies to reservists. \\
\hline $\begin{array}{l}\text { Del Rio v United States, } \\
1987^{12}\end{array}$ & Negligence in prenatal care received. & $\begin{array}{l}\text { Child's claim for prenatal injuries was not barred } \\
\text { under Feres. }\end{array}$ \\
\hline $\begin{array}{l}\text { Carmelo Rodriguez Military } \\
\text { Medical Accountability Act, } \\
2009^{17}\end{array}$ & $\begin{array}{l}\text { Amends the FTCA to allow claims for damages for personal injury } \\
\text { or death of servicemember secondary to negligence in medi- } \\
\text { cal, dental, or other health-related fields. }\end{array}$ & Bill expired without congressional action. \\
\hline NDAA $2020^{23}$ & Troops are able to file claims. & $\begin{array}{l}\text { Authorizes Secretary of Defense to allow, settle, } \\
\text { and pay an administrative claim against the US } \\
\text { government in the context of medical negligence. }\end{array}$ \\
\hline
\end{tabular}

Includes select events and court proceedings starting from the FTCA through the NDAA 2020. Although it covers a majority of the pertinent cases, it by no means is meant to be all-inclusive. This represents the efforts of many servicemembers and their families to fight against the Feres Doctrine principles. ${ }^{1,3-18,23,32}$

physicians to both the National Practitioners Data Bank and state medical licensing groups. . $^{10,19,22}$ Additionally, proponents of the Feres Doctrine point out that only $30 \%$ of the patients cared for in the military's healthcare network are active duty; the rest are beneficiaries and dependents. Thus, $70 \%$ of patients in MTFs are already able to sue the government under the FTCA. ${ }^{17,19}$

\section{The Present-Day Military Medical Malpractice Process}

In April 2019, Representative Jackie Spears introduced the SFC Richard Stayskal Military Medical Accountability Act of 2019, which proposed an exemption to the Feres Doctrine permitting active-duty servicemembers or their representatives to file a medical malpractice claim against certain Department of Defense facilities. Specifically, the exemption would apply to medical malpractice claims arising within major military clinics and hospitals; care provided in the field (i.e., in combat, on ships, or at battalion aid stations) would continue to be protected under Feres. The act was incorporated into the National Defense Authorization Act for Fiscal Year 2020 (NDAA 2020). In doing so, the 116th Congress finally legislated an alternative to the Feres Doctrine. For the first time since 1950 , servicemembers who experience personal injury or die due to medical malpractice by a Department of Defense healthcare provider serving in a covered MTF can seek compensation for injuries resulting from negligent care. ${ }^{23}$ Although the change does not specifically permit medical malpractice lawsuits per se, it grants provisions for servicemembers to file administrative claims with the Secretary of Defense for medical malpractice compensation. Effective January 1, 2020, the NDAA 2020 covers retroactive negligence claims back to January 2017 and has set aside $\$ 400$ million to compensate soldiers over the next 10 years. ${ }^{23}$

\section{Discussion and Implications for Military Medicine}

The last several months of military medicine have seen a change that has been building for 70 years. Whereas medical malpractice lawsuits remain out of reach to active-duty servicemembers, this new administrative claims process, which provides compensation for injuries due to negligent care, could represent the first step toward more drastic changes. Accordingly, military neurosurgeons may soon face litigation like their civilian counterparts.

Neurosurgeons have the highest annual rate of malpractice claims of any medical specialty, with $19.1 \%$ of neurosurgeons facing at least one claim annually. Only $54.2 \%$ of these claims are decided in favor of the surgeon, which is lower than the national average of $75 \%$ across all other specialties. ${ }^{24}$ Healthcare liability costs as a whole are estimated to be more than $\$ 55$ billion in annual healthcare spending, with an additional estimated $\$ 210$ billion in expenses attributed to defensive medicine. ${ }^{25,26}$ The volume 
of claims and damages awarded has increased dramatically in the 21st century, particularly in spine surgery. ${ }^{27-29}$ With the increased litigation risk, spine surgeons are up to three times more likely to practice defensive medicine compared to nonspine neurosurgeons. ${ }^{25,30}$

An important question that needs to be answered is whether tort exposure will decrease medical negligence and improve care. For the time being, military neurosurgeons remain insulated from personal liability, because the FTCA shifts liability to the government. ${ }^{3}$ Therefore, it is unlikely that compensation awarded to injured patients by the military medical system would significantly affect the individual practice of military physicians..$^{21}$ More to the point, even if the threat of litigation were likely to affect individual practice, as we see in the civilian spine literature, defensive medicine does not lead to better patient care. $^{25,31}$

Regarding the NDAA 2020, it remains unclear how claims will be processed and awarded after filing. The Congressional Budget Office estimates \$2.7 billion in spending if claims and awards were to mirror the civilian landscape, in contrast to the $\$ 400$ million set aside under the NDAA $2020 .{ }^{17,19,23}$ While it seems unlikely that $\$ 40$ million awards will be commonplace, with only $15 \%$ of the estimated necessary funding allocated, claimants may be unpleasantly surprised. ${ }^{18}$ Additionally, claimants will bear the cost of all legal fees regardless of whether or not the case is won. Nevertheless, the NDAA 2020 represents an important first step toward compensating servicemembers injured by negligent care, and a significant departure from the prevailing interpretation of federal liability in medical malpractice.

\section{References}

1. Feres $v$ United States, 340 US 135 (1950).

2. Kels CG. Military medical malpractice and "the right to sue." Clin Dermatol. 2012;30(2):181-187.

3. Federal Tort Claims Act, 28 USC $\S \S 1346(b)(1), 2401(b)$, 2671-2680.

4. United States v Brown, 348 US 110 (1954).

5. Layne v United States, 295 F2d 433 (7th Cir 1961).

6. United States v Carroll, 369 F2d 618 (8th Cir 1966).

7. Mattos v United States, 412 F2d 793 (9th Cir 1969).

8. Scales v United States, 367 US 203 (1961).

9. Utley v United States, 624 F Supp 641 (SD Ind 1985).

10. United States v Johnson, 481 US 681 (1987).

11. Joyce Atkinson v United States, 813 F2d 1006 (9th Cir 1987).

12. Del Rio v United States, 833 F2d 282 (11th Cir 1987).

13. Miller v United States, 42 F3d 297 (5th Cir 1995).

14. Witt v United States, 2009 US Dist (ED Cal 2009).

15. Daniel v United States, No. 16-35203 (9th Cir 2018).

16. United States $v$ Shearer, 473 US 52 (1985).

17. Carmelo Rodriguez Military Medical Accountability Act of 2009, S. 1347. Accessed September 14, 2020. https://www. govtrack.us/congress/bills/111/s1347

18. Carmelo Rodriguez Military Medical Accountability Act of 2009, Hearing on HR 1478 Before the Subcommittee on Commercial and Administrative Law of the Committee on the Judiciary, US House of Representatives, 111th Cong, 1st Sess (2009).

19. Carmelo Rodriguez Military Medical Accountability Act of 2009, Hearing Before the Subcommittee on Commercial and Administrative Law of the Committee on the Judiciary, US
House of Representatives, March 24, 2009 (invited testimony of JD Altenburg).

20. Turley J. Pax militaris: the Feres Doctrine and the retention of sovereign immunity in the military system of governance. Geo Wash L Rev. 2003;71(1):1-90.

21. Mangalmurti SS, Murtagh L, Mello MM. Medical malpractice in the military. $N$ Engl J Med. 2011;365(7):664-670.

22. Medical quality assurance in the Military Health System, Department of Defense Directive 6025.13. May 4, 2004. Accessed September 14, 2020. https://biotech.law.lsu.edu/blaw/ dodd/corres/pdf/d602513_050404/d602513p.pdf

23. National Defense Authorization Act for Fiscal Year 2020, S. 1790. Accessed September 14, 2020. https://www.govtrack. us/congress/bills/116/s1790

24. Jena AB, Seabury S, Lakdawalla D, Chandra A. Malpractice risk according to physician specialty. $N$ Engl J Med. 2011; 365(7):629-636.

25. Din RS, Yan SC, Cote DJ, et al. Defensive medicine in U.S. spine neurosurgery. Spine (Phila Pa 1976). 2017;42(3):177185.

26. Solaroglu I, Izci Y, Yeter HG, et al. Health transformation project and defensive medicine practice among neurosurgeons in Turkey. PLoS One. 2014;9(10):e111446.

27. Steele L, Mukherjee S, Stratton-Powell A, et al. Extent of medicolegal burden in neurosurgery-an analysis of the National Health Service Litigation Authority Database. $\mathrm{Br} J$ Neurosurg. 2015;29(5):622-629.

28. Emery E, Balossier A, Mertens P. Is the medicolegal issue avoidable in neurosurgery? A retrospective survey of a series of 115 medicolegal cases from public hospitals. World Neurosurg. 2014;81(2):218-222.

29. Mukherjee S, Pringle C, Crocker M. A nine-year review of medicolegal claims in neurosurgery. Ann R Coll Surg Engl. 2014;96(4):266-270.

30. Rovit RL, Simon AS, Drew J, et al. Neurosurgical experience with malpractice litigation: an analysis of closed claims against neurosurgeons in New York State, 1999 through 2003. J Neurosurg. 2007;106(6):1108-1114.

31. Nahed BV, Babu MA, Smith TR, Heary RF. Malpractice liability and defensive medicine: a national survey of neurosurgeons. PLoS One. 2012;7(6):e39237.

32. Brooks v United States, 337 US 49 (1949).

\section{Disclaimer}

The views expressed in this narrative are those of the authors and do not reflect the official policy of the Department of the Army/ Navy/Air Force, Department of Defense, or US government.

\section{Disclosures}

The authors report no conflict of interest concerning the materials or methods used in this study or the findings specified in this paper.

\section{Author Contributions}

Conception and design: Dewar, Boulter, Curry. Acquisition of data: Dewar, Bowers. Analysis and interpretation of data: Dewar, Boulter, Bowers. Drafting the article: Dewar, Boulter. Critically revising the article: Bell, Dewar, Boulter, Curry. Reviewed submitted version of manuscript: all authors. Approved the final version of the manuscript on behalf of all authors: Bell.

\section{Correspondence}

Randy S. Bell: Walter Reed National Military Medical Center, Bethesda, MD.randy.s.bell.mil@mail.mil. 